\title{
Energy and transformation in alternative pilgrimages to Catholic shrines: deconstructing the tourist / pilgrim divide
}

\author{
Anna Fedele \\ In recent years an increasing number of travelers have visited sites considered 'power \\ places,' with the intention of tapping into their energy and the experiential \\ transformation and healing associated with such sites. This article is based on \\ fieldwork among pilgrims influenced by the international Goddess movement, \\ visiting Catholic shrines in Southern Europe; the analysis reflects an ethnographic \\ perspective on how these pilgrims conceptualize their journeys. Their approach to \\ sacred sites is by no means unique but rather the expression of an engagement both \\ with pilgrimage and tourism, one in which both the notions and experiences of energy \\ and transformation play key roles. I will argue that in the context of these sacred \\ journeys, the use of an energy language to make sense of travel experiences and the \\ emphasis on personal transformation allow the pilgrims to deconstruct oppositions \\ implicitly associated with the tourism / pilgrimage dichotomy (Badone, 2004, p.185).
}

Keywords: Pilgrimage - Tourism - Energy - Transformation - Catholic shrines - Goddess spirituality

\author{
A guru goes to the supermarket and pays with a 200 euro note. \\ The man at the counter takes it \\ then moves on to the next customer. \\ The guru asks him: \\ 'Hey, where's the change?' \\ The man at the counter answers: \\ 'Didn 't you know? The change comes from within.' \\ --Joke told by Dana, leader of one organized \\ pilgrimage group I accompanied
}

When I asked Susanna, an Italian in her late forties who hailed from Rome, what difference there was between the pilgrimage she had made to France in 2003 to connect with the energy of Mary Magdalene, the Goddess and the Cathars and Templars and other trips she had made for recreational or 'touristic' purposes, she said:

'When I went to Burma [on an organized trip] I did the same [energy] practices that we could have done with Juan [one of her spiritual teachers]. From a certain moment of my life onwards, all my travels have become like this. Because when I travel now, I connect myself with the river if there is a river, with the mountain and so on. It happens automatically; before it did not happen, obviously it did not happen.' (April 8, 2005; Fedele, 2013a, p.252)

To my surprise, Susanna, like other travelers I met during fieldwork, saw no perceivable difference between journeys they described as pilgrimages or sacred journeys and those trips made 
for recreational purposes; both offered the opportunity to make contact with the 'energy' of the sites, receive spiritual insights and experience spiritual transformation (Fedele, 2013a).

Between the fall of 2002 and the summer of 2006 I accompanied spiritual travelers to Catholic shrines in France related to Saint Mary Magdalene, including Les-Saintes-Maries-de-laMer (Badone, 2008), Saint-Maximin-en-Provence and La Sainte-Baume, but also shrines such as Saint-Victor in Marseille and the Chartres cathedral where dark madonna statues were venerated (Fedele, 2013b). The pilgrims traveled on their own or on organized tours; the organized groups I accompanied included a British-American group led by Roger Woolger, an Italian group led by Celso, and an exclusively female group of Catalan and Spanish led by an Argentinean woman named Dana.

The pilgrims had Christian (primarily Catholic) backgrounds and had come to reject traditional Christian dogmas and rituals, finding in the worldwide Goddess movement (e.g. Luhrmann, 1989; Pike, 2001; Salomonsen 2002; Magliocco, 2004) new beliefs and practices that better fit their needs. They wanted to 'reclaim the power places' they felt the 'Church' had 'appropriated' and transformed. These pilgrims rejected the Christian religion, which they saw as 'patriarchal,' but they did retain certain Christian rituals, symbols and theories and perceived figures such as Jesus, the Virgin Mary and Mary Magdalene as gods and goddesses. Through creative adaptation, Mary Magdalene had become a female equivalent to, or counterpart of, Jesus rather than the biblical woman who had been transformed by 'the Church' into a repentant sinner. Influenced by texts such as The Holy Blood and the Holy Grail (Baigent, Leigh and Lincoln, 1982) or The Cult of the Black Virgin (Begg, 1985), the pilgrims considered 'Black Madonnas' and Mary Magdalene as representations of a 'dark side of the Feminine,' a manifestation that had been repressed by the "patriarchal Church Fathers.'

When I began fieldwork for my dissertation (Fedele, 2013a) in 2002 and shared my plans with colleagues and friends, several of them expressed the view that the travelers I wanted to accompany were simply 'tourists' who identified as pilgrims to convince themselves and others that their trips were devoted to a noble, rather than merely recreational, purpose. Eager to disprove this assumption, I insistently asked those I accompanied about any differences that might distinguish them from tourists; I was hoping to find elements that would help me argue that these travelers had every right to call themselves pilgrims. The citation at the beginning of this article shows that I failed in my quest. Their answers did, however, lead me to reflect deeply on my own assumptions. For one thing, the word 'pilgrim' proved problematic. The Italian travelers who had a strong Catholic background, especially, perceived the term as a link to their 'patriarchal' Christian upbringing - more so than the label 'tourist.' As recent studies have shown (e.g. Reader and Walter, 1993; Badone and Roseman, 2004), the boundaries between pilgrimage and tourism are blurred; the idea that tourists are simply mindless hedonists (Turnbull 1992, p.259; see also: Taylor, 2001; Coleman and Crang, 2002) while pilgrims are only driven by pious motives has been widely contested. Pilgrims, both in the present (e.g. Frey, 1998, 2005; Coleman and Elsner 1995, 1998; Morinis, 1992) and the past (Smith 1992:7-8; Sumption, 1975), may be motivated by concerns that are not merely spiritual, and tourists can have transformative experiences (e.g. Graburn, 1977, 1983, 1995; MacCannell 1976).

In this text I will use data mainly from my fieldwork among Mary Magdalene pilgrims (2002-2006) and citations derived from those interviews; however, the spiritual theories and practices related to power places emerged during later fieldwork (2009-2011) in Portugal, Spain and in the San Francisco Bay Area, when I spoke to spiritual practitioners who had visited Southern European Marian shrines such as Loreto (Italy), Fatima (Portugal), Lourdes (France) or Montserrat (Catalonia). I will argue that two main elements are crucial to understanding the increasingly popular (e.g. Zwissler, 2011; Dubisch, 2009) kind of sacred journey to power places: the use of an

\footnotetext{
${ }^{1}$ For a detailed discussion of the importance and meaning the pilgrims ascribed to Black Mado nnas see Fedele, $2013 \mathrm{~b}$.
} 
energy language to make sense of travel experiences and the centrality of concepts pertaining to personal transformation. Drawing upon Ellen Badone's analysis of tourism and pilgrimage (Badone, 2004; Badone and Roseman, 2004), I will show how such spiritual travelers use the concepts of energy and transformation to deconstruct common assumptions about differences between tourism and pilgrimage, differences that derive from the Judaeo-Christian and classical heritage of Western culture (Badone, 2004).

\section{The genealogy of 'energy pilgrimages'}

Evidence dating from the late 1970s onward suggests that travelers were visiting places considered 'sacred' and 'powerful' to meditate and draw on its 'energy.' In the 1980s, as organized trips to 'sacred places' and centers also developed, travelers to such places often defined themselves as 'pilgrims' and their trips as 'sacred journeys' or 'pilgrimages.' In recent years social and cultural scientists have described such travelers using terms such as 'ecospiritual pilgrims' (Ivakhiv, 2001, p.49) or 'Goddess pilgrims' (Rountree, 2002, 2006a, 2006b), thereby assimilating them with certain cultural / religious movements such as the 'New Age' and the Goddess movement. Bearing in mind all these terms, I refer here to such spiritual journey-makers as 'energy pilgrims' - an umbrella term I use to refer to those on the Mary Magdalene tours and the pilgrimages to the Marian shrines that I studied, but also to those whose sacred journeys have been analyzed by social scientists, including the aforementioned (e.g. Bowman, 1993; Ivakhiv, 2001; Rountree, 2002). I have chosen 'energy' as a key concept because it relates to one of the main things these travelers have in common, that is, an avid interest in contacting and / or receiving the 'energy' of the places they visit. That the concept is central is supported by the fact that pilgrims use energy language (Fedele 2009) not only to describe their worldview and spiritual practices but also to make sense of their journeys as a whole (Weibel, 2001; Ivakhiv, 2001; Rountree, 2002).

Although social scientists were recognizing sacred journeys to power places in the $1990 \mathrm{~s}$ (e.g. Bowman, 1993), the first book devoted entirely to this new kind of pilgrimage was by cultural geographer Adrian Ivakhiv (2001), who studied Glastonbury in Somerset, England and Sedona in Arizona. Inspired by Lovelock's (1979) Gaia: A New Look at Life on Earth, 'Gaian pilgrims,' as observed by Ivakhiv (2001, p.4), considered the Earth a sacred feminine being and certain places were 'Earth's theophanies' (2001, p.49). Concerned with ecology, these pilgrims saw the Earth as a living being that needed to be protected from humanity's pitiless exploitation and believed it should be revered as it had been by ancient populations and still was by certain indigenous groups.

Influenced by Watkins' The Old Straight Track (1925) and later books that referred to Watkins, Gaian pilgrims believed that the Earth is crossed by lines of energy ('ley lines') that form a web, ${ }^{2}$ and that places where two or more of these lines cross are particularly powerful. These points had once been known to the 'religious specialists' of ancient religions, who had built sacred monuments upon them. As far as Gaian pilgrims were concerned, visiting such places was beneficial; they believed that people could avail themselves of the energy present and thereby gain healing and insight (Badone, 1991).

As the result of the spread of such 'spiritual travelling,' guidebooks appeared in the early 1980s that offered information about meditation centers, vegetarian restaurants and spiritual retreats to power places in several countries. A Pilgrim's Guide to Planet Earth. A Traveler's Handbook and New Age Directory (1981) is an early example (Weibel 2001, pp.106-107). In the foreword, the editor, Parmatma Singh Khalsa, states:

\footnotetext{
${ }^{2}$ For a scientific rebuttal of the theory of ley lines, see Williamson and Bellamy, 1983; for a detailed discussion of the evolution of the theories about ley lines and of ley hunters, see Ivakhiv, 2001.
} 
'A Pilgrim's Guide to Planet Earth' is both a travel guide and international directory. But its essence is beyond this. Its purpose is to raise our consciousness toward Planet Earth. It is to present access to the sacred places of Earth -natural, ancient, modern and to the people who reside there. These sites, as focal points of energy and consciousness, are important to people and to the planet itself.'

As Ivakhiv has shown, Gaian pilgrims 'consider themselves part of an emerging New Age of spiritual and ecological awareness' and reject the disenchanted vision of the world that they saw 'science' offering (2001, p.3). Overlapping in some cases with those in the counterculture movement, such pilgrims oppose capitalism and globalization, proposing instead an alternative 'eco-spirituality.' When visiting sacred places, for instance, meditation or the use of 'energy techniques' are employed to tap into the healing influences of the place and sometimes to 'donate their own energy' to the site. By so doing they 'empower themselves' and honor Gaia, 'Mother Earth.' ${ }^{3}$ They see this as contrasting humanity's general exploitative attitude towards the planet, and believe that meditating and projecting positive thoughts can contribute to healing the 'Earth' (Ivakhiv, 2001).

Although there are said to be 'powerful places' throughout the world, some sites such as the pyramids of the ancient Egyptians and Mayan and Incan archaeological sites are a special draw to Gaian pilgrims. In Europe, Gaian travelers are attracted to Gothic cathedrals and pre-historic stone circles such as Stonehenge in Wiltshire, England. These structures are thought to have been built at powerful places, according to the rules of a secret 'geomancy':

'There are many such sites (power points) all over our planet - Glastonbury and Stonehenge in Britain, Tihuanaco in Bolivia, Easter Island in the Pacific and MT. Shasta in California. In France, Chartres Cathedral stands on a large prehistoric mound over a buried chamber, and this, according to Louis Charpentier (who wrote "The Mysteries of Chartres Cathedral"), is the natural meeting place of several powerful streams of telluric (earth) currents (also called "Leylines"). Here the Christian geomancers, whose hidden influence within the Church was active during the Middle Ages, sited and built their miraculous structure to serve as an instrument for the accumulation and fusion of energy and for its dissemination to the benefit of the locality and of the pilgrims who at certain seasons crowded the Cathedral.'

(Khalsa 1981, p.14)

According to Fulcanelli's theories in Le Mystère des Cathédrales et l'interprétation ésotérique des symboles hermétiques du grand œuvre (1929) — later recovered and further developed by Louis Charpentier in his book on the Chartres cathedral (1966) - certain orders of masons (Christian geomancers), particularly those linked to the Order of the Knights Templar, built most of the Gothic cathedrals according to their secret knowledge of telluric currents and astronomy. The pilgrims I accompanied not only shared the theories and practices of Gaian pilgrims, they were particularly interested in power places related to the Cathars and the Templars. In fact, the pilgrims considered these heretic orders to be forerunners of the contemporary Goddess movement. 'Goddess pilgrims,' as studied by Kathryn Rountree (2002, 2006a, 2006b), have several things in common with Gaian pilgrims but are more focused on 'feminist' issues and so visit places related to what they identify as 'ancient matriarchal cultures' to worship 'the Goddess' through

${ }^{3}$ The fact that Lovelock has chosen the name of a Greek goddess to identify the earth as a living being has led people to identify the planet with the goddess and, further, with the general idea of 'Mother Earth'; see also Hanegraaff, 1996, pp.155-158. 
dancing, chanting and through particular rituals in places where 'She' was venerated a long time ago (Eller 2000, pp.22-23). In Leila Castle's Earthwalking Sky Dancers. Women's Pilgrimages to Sacred Places (1996), different women from the Goddess movement talk about their personal journey to the 'Sacred Feminine' in places all over the world. In the foreword, Riane Eisler, one of the most influential authors of the movement, recounts an experience she had in Austria:

'I had stopped at the village for dinner on the way to Vienna where I was born, and on impulse I had decided to drive up the hill to look at the sunset before dusk. The church was small and baroque, white with carved wooden portico. What intrigued me was the sign on it: 'Frauenkirche'. A Women's Church. At that time I was still on the threshold of the journey of exploration that eventually led me to 'The Chalice and the Blade', 'Sacred Pleasure', and other works reclaiming our lost Goddess heritage. But I already knew that if there was a church on a high place called Women's Church, it must be on a very ancient site: a site dating back to a time when women were priestesses and the powers that govern the universe were not yet imaged only in male form.'

Eisler's account resonates with many spiritual practitioners who find not only that pagan temples in Turkey, Greece, Malta or Italy, as described by Rountree (2002a, 2002b), may be used to connect with the Goddess' power, but Christian churches as well (Weibel 2001, Badone 2008). Those built on high places, in particular, with names that refer directly or indirectly to the 'Sacred Feminine' are thought to have been constructed at sites of pagan temples once dedicated to the 'Goddess.' Women from the transnational Goddess movement are now reclaiming these sites and performing creative 'pagan' rituals thought to derive at least partially from ancient pre-Christian traditions.

Ivakhiv (2001, p.231) and Rountree $(2002,2006 \mathrm{~b})$ have underlined the difficulty of differentiating this kind of pilgrim from tourists in general. Particularly in the case of pilgrims traveling in organized groups such as those described by Rountree, similarities to tourist groups visiting the same sites are striking, including traveling in air-conditioned coaches, eating in good restaurants and visiting archaeological and historical museums. Rountree argues that 'the contemporary Goddess pilgrim epitomizes the traveller who straddles the tourist/pilgrim divide, possessing important elements of both as well as some distinctive characteristics' (2002).

There are key differences, however. In open opposition to Catholic pilgrims, Goddess pilgrims consider physical pleasure to be an important part of the pilgrimage and criticize the division of the spirit and the body, which they ascribe to 'Judaeo-Christian patriarchal schemes.' The pilgrims I encountered share the basic assumptions of Gaian and Goddess pilgrims but their interest focuses on 'power places appropriated by the Church,' usually considered places where Pagan divinities were venerated before the arrival of Christianity (see Eisler, previous citation). The pilgrims were also assiduous readers; I have argued (2013a) that in order to understand them it is essential to pay close attention to the spiritual literature they consult throughout their journeys. The leaders of the three organized Mary Magdalene pilgrimages I accompanied read book excerpts that backed up their assertions, and Roger Woolger provided his group with a reading list of titles on feminine spirituality, Mary Magdalene, Black Madonnas, pilgrimage and other themes related to his tour. Like the Glastonbury pilgrims described by Ivakhiv (2001) and Bowman (1993) and the women studied by Weibel who visited Rocamadour (2001), the energy pilgrims I talked to contested the use the 'Church' had made of these sites. Some even charged the Church with theft (Fedele 2013a, 97-109). The journey, then, was vital, allowing them to tap into the ancient energy of the site - an energy that supposedly pre-dated Christianity and the distorting transformations of the Church. 


\section{Energy and transformation}

My interlocutors derived most of their ideas and practices from American and British Neopaganism, but they did not consider themselves 'Pagans'. Influenced by their Christian backgrounds, the pilgrims tended to regard the term as having negative connotations; 'Pagan' was too emotionally charged to use, and so the pilgrims preferred to speak more generally about a feminine spirituality (Fedele, 2013c).

As with Neopagans in the United States (among others: Magliocco, 2004; Pike, 2001), the pilgrims I met criticized institutionalized religion, particularly Christianity, as patriarchal and misogynist. They held that the Christian vision of the body as a 'place of sin' led Christians to despise the material world and to perceive their sexuality as sinful. This general rejection and denigration of body and matter is, according to Neopagans, one of the principal causes of both the current ecological disaster and of the widespread sexual abuse such as child molestation or the rape of women. In order to halt this process, Neopagans advocate a sacralization of body and sexuality and a vision of nature and the planet Earth as inhabited by divine forces. Energy pilgrims shared this perspective and considered the world-denial and body-mortifying Christian attitude to be the starting point of most present evils and the principal cause of the exploitation of the planet. They emphasized the need to 're-consecrate matter' and to recover a deep connection with the Earth, identified as a divine feminine being called 'Mother Earth.' Like Neopagans, energy pilgrims often referred to an ancient pre-Christian and pre-patriarchal cult of the Goddess celebrated by their European and American ancestors.

The pilgrimages I studied were devoid of the usual features: there was no specific final goal, no specific religion associated with the trip and no stereotypical ritual actions to perform. Even so, many of the participants described themselves as pilgrims. Mary Magdalene and the Virgin Mary were both reference points — the places visited were mostly Catholic shrines — but so too were caves, waterfalls, castles and Roman ruins. At first glance, the Europeans and Americans traveling in groups with their own cars or in a tour bus, visiting churches, taking pictures and listening to the explanations of their leaders looked superficially like tourists. But the aim of their journeys, they emphasized, was spiritual; they were searching for direct contact with divine forces, to understand better their own innermost needs and to experience personal change. Most of them were also seeking special healing, and made requests at shrines they perceived as particularly powerful. All the pilgrims I accompanied told me about certain 'energy connections' they had made during their trips; they established these connections by either drawing on their ow $n$ experience or by following the instructions of the leader. Pilgrims from the Italian and Spanish groups also devised elaborate creative rituals intended to bring about empowerment and healing (Fedele, 2013a, Fedele, 2014a).

As I have mentioned, some of my interlocutors had more problems with the term 'pilgrim' than that of 'tourist.' Not surprisingly, given that the Italians were from the country with the most important Christian pilgrimage site in Europe, they did not like the term 'pilgrimage' (pellegrinaggio) and preferred to describe their trip as a 'journey of initiation' (viaggio iniziatico). The difference between 'pilgrimage' and 'journey of initiation,' they explained, was that the latter was free from Catholic connotations and evoked a spiritual quest divested of Christian-infused concepts such as expiation, suffering and redemption.

In general, the pilgrims preferred to use terms they perceived as neutral, this is, not inscribed in any existing religion. Reference to 'energy' was omnipresent in their discourse, allowing them to navigate various religious and scientific domains, and to draw on references from existing religions, as well as psychology, quantum physics and anthropology. The pilgrims held that everything was made of energy - an all-pervading divine life force that manifested itself through the material world. People needed to become aware of and take care of their 'energy body' or the 'aura' that enveloped the physical body. The pilgrims knew different energy techniques to receive 'light' or 'positive' nurturing energy from the surrounding world, and to release to 'Mother Earth' the 
'heavy' or 'negative' harmful energy. They considered negative emotions such as fear, anger or sadness as expressions of the heavy energy in their energy body, and used power places to release these emotions.

Like the Italian Susanna, other pilgrims told me that ever since they had developed a different relationship with 'Mother Earth,' having learned to distinguish and make use of the different kinds of energies available in certain places, every trip had become a pilgrimage. I asked Susanna's friend Luciana what difference there was for her between a trip and a pilgrimage, and she answered:

'From my point of view, as an individual, there is no difference at all. Because a trip does not only represent for me the pleasure of seeing a place, it implies a spiritual practice that I do on myself first of all. Even if I go, for instance, to Grottaferrada nearby [just outside Rome], this can offer me the departure point for something [a spiritual insight]. I mean, I am very open and therefore I leave a lot of space for the emotions that come up in order to get me working on myself. For this reason, every trip is a pilgrimage. If I visit places that also have a particular, more evident power, then this experience becomes even more striking, probably because it is the energy of that site that has a stronger influence on me (...) As I am very open to situations and places, there is no separation between me and the rest of the world and it really is as if I were a pilgrim walking 365 days a year.' (April 9, 2005; Fedele 2013a, pp.252-253)

As is clear from Luciana's discourse, describing and perceiving places in terms of energy allowed my interlocutors to overcome the distinction between pilgrimage and tourism and to conceptualize every travel experience as potentially empowering.

Jorgen Bærenholdt, Michael Haldrup, Jonas Larsen and John Urry have argued that "tourist places should not be seen as necessarily involving strange, remote or exotic places" and that "tourism is not so much about going places as it is about particular modes of relating to the world in contemporary cultures" (2004:2). Pilgrimage places can be viewed in a similar vein-not as necessarily involving (only) sites deemed relevant within a certain religious tradition. In this context pilgrimage is not always related to visiting special places; it is rather linked to a particular way of engaging with the world in terms of energy. As we will see from Margot's experience below, even if certain places form part of the itinerary of an organized pilgrimage, they are not necessarily the only sites where the pilgrims experience spiritual insights or healing. It can therefore be useful to consider the sites visited by the pilgrims not as "relatively fixed entities", but rather as "fluid and created trough performance" (Coleman and Crang 2002:1).

The other important component of the pilgrimage experiences, related directly to that of energy, was that of personal transformation. When talking about what had moved them to visitcertain power places, many of my interlocutors mentioned things they wanted to transform or heal, thanks to the energy present in those sites. Indeed, personal transformation attained through a ritual process of initiation (Graburn, 1977) was a key element of these journeys. Italian pilgrims, for instance, were invited to begin their journeys by formulating what those desired changes would be (Fedele, 2013a, pp.61-64), whereas Spanish pilgrims heard from their leaders that, as would be the case with other rituals of initiation, the pilgrims could expect a clear before-and-after to the pilgrimage (Fedele, 2013a, p.6).

For the Mary Magdalene pilgrims I accompanied, the trip to France was an occasion for getting in touch with people with whom the travelers had a spiritual affinity and to heal certain aspects of themselves (Fedele, 2012, 2013a, 2014a). However, the journey was also a challenge. As some explained to me, the pilgrimage itself - a group of people pursuing a similar spiritual goalwas a powerful catalyst for personal transformation, and transformation was not always an easy 
experience. As we can see from the example below, the emotional consequences of traveling in a group were also conceived of, and dealt with, in terms of energy. Felicia, a Catalan pilgrim in her fifties traveling in the Spanish / Catalan group led by Dana, explained:

'During pilgrimages, there are many energies on the move. You do not find only rosy experiences, there also is the pain, feeling ill at ease and there are very powerful dreams. Suddenly you see things of your life in front of you, flash! there you see them. And there are very painful things. If you do not systematically take time out to get in touch with your inner feelings, you miss the things that come up, you lose the opportunity. [During our trip] there was some degree of stress, you had to move on (...) to eat in a hurry and so on. I cannot speak for the others but I felt that at some moments I needed calm and silence and did not have it because some of the group kept talking [iba de cháchara].' (June 17, 2005; Fedele 2013a, p.251)

For Felicia, personal transformation was a conscious goal, both for her and for many other pilgrims; like her, others also complained about the fact that the behavior of fellow pilgrims prevented them from taking advantage of the transformative experiences fostered by the pilgrimage experience. Felicia criticized certain women of the group who did not always have what she perceived as the right attitude for a pilgrimage, for instance, silence and introspection. From Felicia's perspective, an inappropriate attitude prevented the chatty women from experiencing transformation themselves; at the same time, their behavior made it more difficult for Felicia to find the calm she needed to confront the inner feelings she was facing.

Vittorio, an Italian traveling with his wife and son, also criticized fellow pilgrims who, according to him, did not focus enough on their spiritual development:

'I saw several people on this trip, at least half of them, if not more, who were not on a quest because they wanted to discover [something], they were on a quest because it was trendy [era una moda]. This really annoyed me. And I noticed this in small things: the hurry they were in, the places they wanted to go to. (...) Anyway I liked the tour because it has helped me to understand that you have to be careful and see if you are on a quest for others or for yourself. (...) Because there is also this [tendency to brag] "I have been there", but normally it is more an investigation you do on behalf of others [to show off], so that you can say: "I have been there, I did that Templar stuff, I have seen this and that, I have understood this and that." (September 28, 2005)

I have shown elsewhere that the pilgrims were by no means passive recipients of theories and practices they had read about in books or learned from their leaders (Fedele, 2009, 2013a). Just so, they sometimes criticized fellow pilgrims as well as how their leaders were leading the tour or had organized certain rituals (Fedele 2014b). Pilgrims had multiple, sometimes contradictory, approaches and discourses about their status and that of their fellow travelers. Other scholars (e.g. Claverie, 2003; Dubisch, 1995; Hermkens, Jansen and Notermans, 2009) have shown that it is difficult to grasp the essence of religious experiences in general and pilgrimages in particular because every pilgrim undergoes a unique experience that cannot be reduced to general theories but that needs to be understood as part of a complex system of emotions, negotiations, ambiguities and yearnings. That said, in the case of the energy pilgrimages I am analyzing, the reference to energy and the desire to experience a transformative journey were important interrelated elements - it was through the energy at the power places visited and through the energies moved by the pilgrimage group that personal change even became possible. 


\section{Transforming dichotomies}

In her analysis, 'Borderlands between Ethnography, Toursim and Pilgrimage' (2004, pp. 180-190), Ellen Badone notes that 'the prevalent Western characterization of tourism as frivolous and hedonistic (...) is derived from a set of implicit oppositions in Western thinking that are thems elves the product of the Judeo-Christian and classical heritage':

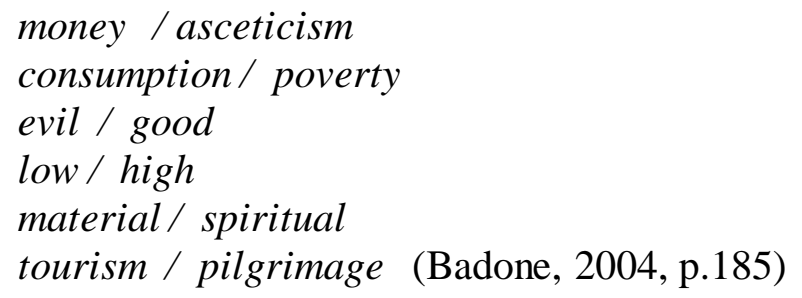

These implicit oppositions are particularly useful for understanding the energy pilgrims I accompanied because my interlocutors overtly criticized and opposed the Judaeo-Christian tradition as patriarchal. As a consequence, they constructed their own spirituality in opposition to a patriarchal ideology (Fedele and Knibbe, 2013) that condemns the body, sexuality and, in general, the material aspects of life, and that thereby legitimizes the exploitation of the planet and the domination and devaluation of women as sinful daughters of Eve (Fedele, 2014a).

Because of their Catholic backgrounds, many pilgrims were well aware of the existence of the above dichotomies and had learned to associate pilgrimage with asceticism and poverty (see Margot's comments below). However, these beliefs were gradually transformed, and, as we will see, energy language played an important role in this process.

American and British pilgrims led by Roger Woolger, in particular, did not perceive the fact that they had paid a relatively high sum of money for their trip, slept in 4-star hotels and eaten in good restaurants as obstacles to their spiritual experiences. ${ }^{4}$ Material well-being did not appear problematic; the general argument was that the value of 'money,' being just another form of 'energy,' depends on the way one uses it. Roger had his own ideas about organizing a pilgrimage, as this was the 'sixth (or seventh tour)' he had led. According to him, the pilgrim should be relieved of worry about accommodations, routes and restaurants so that inner transformation and insights could take place. Nevertheless, the joke cited at the beginning of this articles suggests that the pilgrims were not unaware of folk and social theories (e.g. Carrette and King, 2005) depicting New Agers as consumers, and their gurus as eager for money.

From the pilgrims' point of view, body and soul were intertwined (Fedele and Llera Blanes, 2011); both were made of energy and could be healed and empowered, thanks to the energy present in power places. In order to ascend spiritually one did not need to renounce bodily pleasures; on the contrary, the pleasure of the body was linked to the well-being of the soul. Margot, a poet and storyteller living in the Findhorn community in Scotland, found that one of the important spiritual experiences during her pilgrimage happened while she was taking time 'off,' indulging in mundane, bodily pleasure - receiving a massage. Her poem describes the experience ${ }^{5}$ :

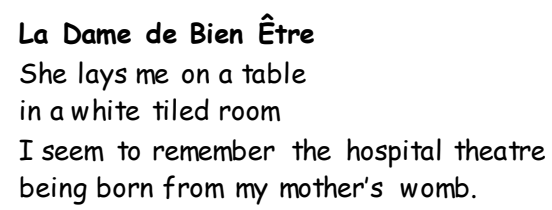

${ }^{4}$ Woolger's 'Magdalenetour' was the most expensive organized pilgrimage I accompanied; Italian pilgrims slept in cheaper hotels and Dana's group slept in hostels, summer camps and once even on the beach. Pilgrims traveling on their own usually chose cheap accommodations.

5 Poem by Margot Henderson, used with the author's permission, Fedele 2013a, pp.236-237. 


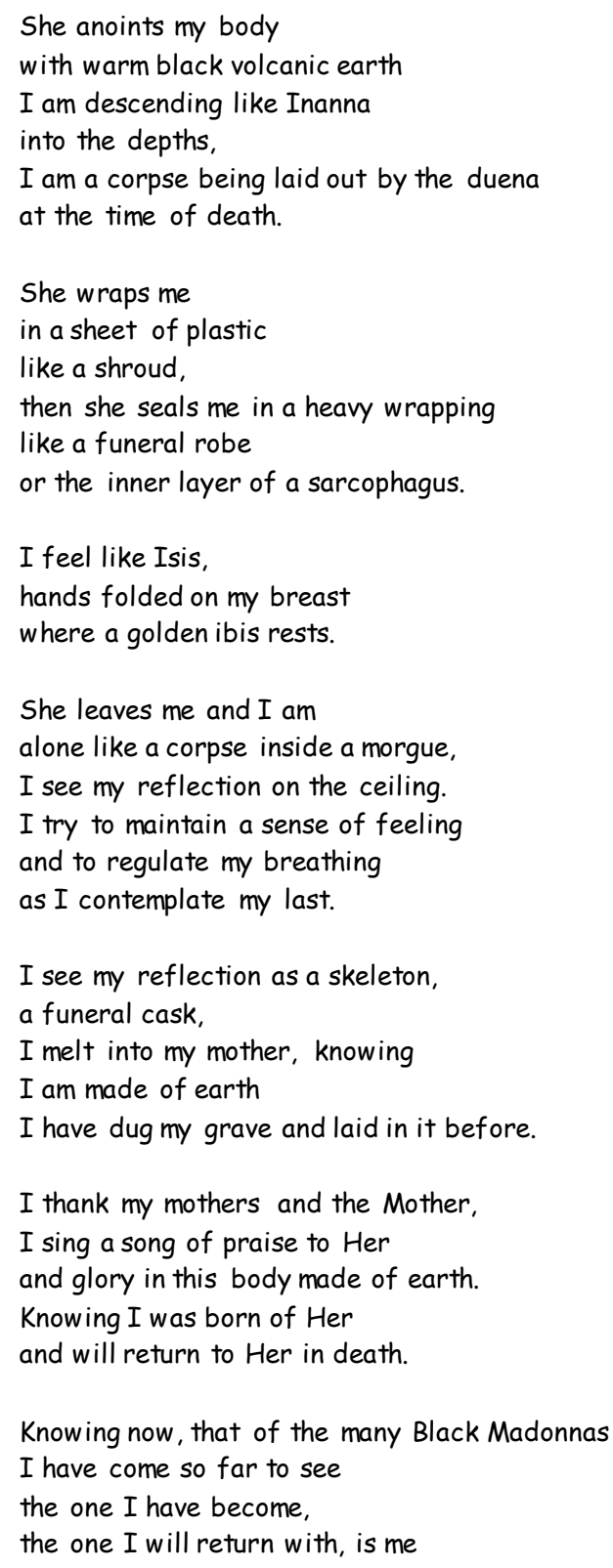

As we can see, a massage by a woman who did not radiate any particular spiritual skills or intentions fostered deep insights for Margot into the vanity of the mundane, connections with the divine and a symbolic encounter with death.

As for the distinction between good and evil, the general discourse among pilgrims was that these two extremes did not exist as such but simply reflected moral judgment. Similarly to how Christianity had labeled the body as impure and therefore linked to evil, other things labeled as 'evil' in Christian terms, homosexuality for instance, were in fact neither good nor evil in absolute terms. For this reason, rather than refer to good or evil, pilgrims talked about positive and negative energy and about the need to release the latter in order to avoid conflict, disease and so on. Vittorio observed:

'Well, a pilgrimage is when you go to places where it is believed or it is said or anyway you feel that certain persons have been. In this case it can be Mary Magdalene or the Madonna or somebody like them. (...) When I talk about pilgrimage I always refer to a way of making pauses, think, stop, meditate and then 
eventually if you happen to be in places where you can release certain energies, to release them. (...) Anyway it always represents a way to stop and think, much more than you normally do.' (September 28, 2005)

Considering that the divine was immanent, pervading the whole universe in form of energy, the pilgrims did not distinguish between low / high in a hierarchical way but referred to different supernatural entities such as 'Father Sky' or 'Mother Earth.' In a similar way, they considered that, with the right approach, every contact and experience could have spiritual connotations; one might just readily gain spiritual insight in a souvenir shop or from going to a spa.

Other activities normally related to tourism, including consulting travel guides or hiring local guides to gain more information about the destinations, also formed part of the energy pilgrimages. Reframing these activities with an energy language, the pilgrims found that a particularly beautiful souvenir replica of a Black Madonna could be charged with the energy of the shrine, and thereby serve as a vehicle for further connections with the place once the pilgrims were back home. Similarly, 'touristic' information gathered from a written or oral guide could help when trying to grasp details about the energetic peculiarities of a place, or to find particularly powerful spots for attaining personal transformation and healing.

Notably, even if they criticized the Christian ideal of pilgrimage, energy pilgrims were not immune to its pervasive influence as a model. Notions of renunciation and redemption, for instance, emerge from Margot's account, below. Used to living frugally, with little money, Margot had organized a fundraising party so she could join Roger's 'Magdalenetour' for her fiftieth birthday. She had set out for the trip with the image of a pilgrim as one who renounces earthly things and had even thought about shaving her head, in expectation of a process of renunciation and elevation. Once she had arrived in Marseille and met the remainder of the group, however, she realized that, on the contrary, she would be leading a much more comfortable life on the road than she did at home in Scotland. For Margot, Christian concepts about how a pilgrim should behave gave way to references of energy transformed:

'And when I came to Marseille what happened was a real rising of sexual energy, a rising of a kind of sexuality and a real, you know, I stepped into the pilgrimage and it was much more of a "yes" to the pleasures of life as well. The kind of delights of eating and drinking and comforts and, yes, celebrating femininity and all of that. So it has been a different journey. You know I had thought about shaving my head but then I realized, no, this isn't the energy of Magdalene really.' (October 2, 2005; Fedele 2013a, p. 235)

Inevitably, the pilgrims' Christian backgrounds prompted references to Christian pilgrimages to Jerusalem, Rome or Compostela. In the slideshow Roger Woolger organized in Marseille on the second evening of the pilgrimage, the first slide depicted a medieval Christian pilgrim, followed by those of images of pilgrims arriving on a boat, then Santiago de Compostela and the map of the different 'Camino' routes from France. He explained that his pilgrims were not going to Compostela, but would see many of the places associated with it: Arles, Le-Puy and Vézelay were among the major places to begin the Camino in France. Roger explained to me that he acted as a sort of psychopomp (Fedele 2013a, p.62), leading people to places he had found to be particularly powerful so that others could, in turn, experience their own personal transformation. He described pilgrimage as an inner journey (Graburn and Barthel-Bouchier, 2001), fostered by the energy encountered in the places visited:

'With our focus on the Magdalene and the Black Madonnas, we are going on a different kind of pilgrimage to find something that is probably as much inside 
ourselves as outside ourselves (...) A pilgrimage is, I think, always an inner and an outer experience. There's an outer focus, I have to get to Rome, to get to Jerusalem, I have to get to Compostela, but all the time on the road we are turning something over in our minds, in our fantasies, in our dreams. That is what I am encouraging people to do. It means that even if we are all on the same physical journey, we are all doing different inner journeys.' (October 1, 2005)

Roger's comments summarize the elements we have been considering: the importance of concepts of energy and transformation, the pilgrims' desire to establish a different approach to Catholic shrines, and to alter the meaning and the influence that their Christian, mostly Catholic, heritage exerted. Roger's observations also highlight the difficulty of capturing the meaning of pilgrimage in general - although we ethnographers can follow the outer journey, it is difficult to capture the mechanisms and meanings of the inner journey, a journey that varies powerfully from person to person.

\section{Conclusion}

To do justice to 'energy pilgrimages,' social scientists need to develop new strategies that go beyond the dichotomies inherent in many theories about pilgrimage and tourism (Reader and Walter, 1993; Badone and Roseman, 2004) and allow us to see the visited places as "fluid and created through performance" (Coleman and Crang 2002:1). We also need to be prepared to overcome the negative preconceptions about tourists (among others: Mac Cannell, 1976; Graburn, 1977, 1983; Turnbull, 1992; Badone and Roseman, 2004) as well as the excessive idealization of medieval pilgrims (Smith, 1992, pp.7-8; Sumption, 1975).

The travelers I encountered were neither 'ideal pilgrims' driven exclusively by a desire for spiritual transformation nor 'greedy tourists' animated only by their quest for bodily pleasure and consumption. Like many other human beings traveling to unknown places, they had an enthusiastic, sometimes critical, often contradictory approach to the people and places they encountered; and they had a profound yearning to understand and transform themselves and to share their joy and trouble with other persons on a similar quest.

I have argued here that to understand these spiritual travelers it is important to take into account their own use of an energy discourse to make sense of their travel experiences and their focus on personal transformation. Energy and transformation are key common elements of alternative pilgrimages to Catholic shrines but also of sacred journeys to historical or archeological sites described as power places.

The pilgrims considered personal transformation a principal aim of their sacred journeys and visited power places in hopes that the energy present there would help them get in touch with their inner feelings, change certain attitudes and attain spiritual insights. A term not inscribed in any existing religious tradition, 'energy' helped my interlocutors to break free from the constrictions they perceived as having derived from their Christian past, and to transform the meanings commonly associated with Catholic shrines or, in general, with Christian pilgrimage.

Pilgrims wanted to overcome what they perceived as limiting attitudes towards body, gender and sexuality inherent in their Christian heritage, and they deconstructed the tourist-pilgrim divide and the oppositions associated with what derives from the Judaeo-Christian and classical roots of Western thought (Badone, 2004, p.185).

Visiting power places in order to profit form their energy is becoming an increasingly popular way of traveling the globe. It will be interesting to observe how those in charge of these 
(often Catholic) sites deal with the consequences of this rising phenomenon. Perhaps the kind of transformation the pilgrims seek, both by changing the meanings ascribed to sites and by working towards their own spiritual development, will also transform the way in which such places are organized and made accessible to visitors of all kinds.

\section{Acknowledgments:}

This article is based on my dissertation, published as Looking for Mary Magdalene: Alternative Pilgrimage and Ritual Creativity at Catholic Shrines in France (Oxford University Press, 2013). Some parts of this text appear in Chapter 8 (pp. 252-253) of the book, and some citations appear throughout the work as a whole; exact references can be found throughout this text. An earlier version of this article was presented at the International Symposium, 'Sacred Tourism, Secular Pilgrimage: Travel and Transformation in the $21^{\text {st }}$ Century' (2011), organized by Sofia Sampaio, Cyril Isnart and myself at the Center for Research in Anthropology of the Lisbon University Institute, and I thank especially Dionigi Albera, Ellen Badone, Maria Cardeira da Silva, Nora Demarchi, Nelson Graburn, David Picard and Fréderic Vidal for their useful comments. I would like to thank Cyril Isnart, Sofia Sampaio and Valerio Simoni for their patience, their support and their attentive remarks and suggestions. I am grateful to Susan Scott for her help with editing. 


\section{References}

Badone, E. (2004). "Crossing Boundaries: Exploring the Borderlands of Ethnography, Tourism and Pilgrimage." In Intersecting Journeys: The Anthropology of Pilgrimage and Tourism. Eds. Ellen Badone and Sharon R. Roseman. 180-189. Urbana and Chicago : University of Illinois Press.

Badone, E. (2008). Pilgrimage, tourism and The Da Vinci Code at Les-Saintes-Maries-de-la- Mer, France. Culture and Religion 9:1, 23-44.

Badone, E. (1991). Ethnography, Fiction and the Meanings of the Past in Brittany. American Ethnologist 18: 518-545.

Badone, E. and Roseman S. R. (2004). Intersecting journeys; the anthropology of pilgrimage and tourism. Urbana and Chicago: University of Illinois Press.

Bærenholdt, J. O. et al. 2004. Performing Tourist Places. Aldershot: Ashgate

Begg, E. (1985). The Cult of the Black Virgin. London: Penguin Books Arkana.

Baigent, M., Leigh, R. and Lincoln, H. (1996, orig.1982). The Holy Blood and the Holy Grail. London: Arrow Books

Bowman, M. (1993). Drawn to Glastonbury. In: Pilgrimage in Popular Culture, I. Reader and T. Walter eds. Pilgrimage in Popular Culture. London: Macmillan.

Claverie, E. (2003). Les guerres de la Vierge. Une anthropologie des apparitions. Paris : Gallimard Coleman, S. and Elsner, J. (1995). Pilgrimage. Past and Present in the World Religions. Cambridge, MA: Harvard University Press.

Coleman, S. and Elsner, J. 1998. Performing pilgrimage: Walsingham and the ritual construction of irony. In Ritual, performance, media, ed. Felicia Hughes-Freeland, 46-65. London: Routledge.

Coleman, S. and Crang, M. (2002). Grounded Tourists, Travelling Theory. In Tourism: Between Place and Performance. Eds. Simon Coleman and Mike Crang. 1-17. New York and Oxford: Berghahn Books

Dubisch, J. (1995). In a Different Place: Pilgrimage, Gender, and Politics at a Greek Island Shrine. Princeton: Princeton University Press.

Dubisch, J. (2009). Encountering Gods and Goddesses: Two Pilgrimages to Greece. CrossCurrents. September 2009: 283-299.

Eade, J., and Sallnow, M.J. eds. (1991). Contesting the sacred: The anthropology of Christian pilgrimage. London and New York: Routledge. 
Eller, C. (1993). Living in the lap of the Goddess: The feminist spirituality movement in America. Boston: Beacon Press.

Fedele, A. (2009). From Christian religion to feminist spirituality; Mary Magdalene pilgrimages to La Sainte-Baume, France. Culture and Religion 10 (3): 243-261.

Fedele, A. (2012) Gender, sexuality and religious critique among Mary Magdalene pilgrims in Southern France. In: Old Routes, New Journeys; Gender, Nation and Religious Diversity st European Pilgrimage Shrines. Willy Jansen and Catrien Notermans eds. 2012, Farnham: Ashgate

Fedele, A. (2013a). Looking for Mary Magdalene: Alternative Pilgrimage and Ritual Creativity at Catholic Shrines in France. Oxford Ritual Studies. New York: Oxford University Press.

Fedele, A. (2013b). 'Black' Madonna Versus 'White' Madonna. Gendered Power Strategies in Alternative Pilgrimages to Dark Madonna Shrines. In: Gender and Power in Contemporary Spirituality: Ethnographic Approaches. Anna Fedele and Kim Knibbe eds. London and New York: Routledge, pp. 96-114.

Fedele, A. (2013c). The Metamorphoses of Neopaganism in Traditionally Catholic Countries in Southern Europe. In: Mapril, José, and Llera Blanes, Ruy, ed. Sites and Politics of Religious Diversity in Southern Europe. Leiden: Brill, pp. 51-72.

Fedele, A. 2013d. 2012, the Spiritualized Prophecy that Could not Fail. Religion and Society: Advances in Research Vol. 4.

Fedele, A. (2014a). "Reversing Eve's Curse: Mary Magdalene, Mother Earth and the Creative Ritualization of Menstruation.” Journal of Ritual Studies.

Fedele, A., and Llera Blanes, R. eds. (2011). Encounters of Body and Soul in Contemporary Religious Practices: Anthropological Reflections. Oxford and New York: Berghahn Books.Fedele, A., and Knibbe, K. eds. (2013). Gender and Power in Contemporary Spirituality: Ethnographic Approaches. New York: Routledge.

Frey, N. L. (1998). Pilgrim stories. On and off the way to Santiago. Berkeley and Los Angeles: University of California Press.

Frey, N. L. (2005). Stories of the return: Pilgrimage and its aftermaths. In: Intersecting journeys: The anthropology of pilgrimage and tourism, eds. Ellen Badone and Sharon R. Roseman, 89-109. Urbana and Chicago: The University of Illinois Press.

Fulcanelli. (1964 orig. 1929). Le Mystère des Cathédrales et l'interprétation ésotérique des symboles hermétiques du grand œuvre. Paris: Jean Jacques Pauvert. 
Graburn, N. H. H. (1995). Tourism, Modernity and Nostalgia. In The Future of Anthropology: Its Relevance to the Contemporary World. Akbar S. Ahmed and Cris N. Shore, eds. Pp. 158178. London: Athlone.

Graburn, N. H. H. (1977). Tourism : The Sacred Journey. » In Hosts and Guests : The Anthropology of Tourism. Ed. Valene L. Smith. 17-31. Philadelphia: University of Pennsylvania Press.

Graburn, N. H. H. (1983). The Anthropology of Tourism. In The Anthropology of Tourism, ed. Nelson H. H. Graburn. Special issue, Annals of Tourism Research 10:9-33.

Graburn, N. and Barthel-Bouchier, D. (2001). Relocating the Tourist. International Sociology, vol. 16 no. 2 , pp. 147-158.

Hermkens, A., Jansen W. and Notermans C., eds. (2009). Moved by Mary; the power of pilgrimage in the modern world. Farnham: Ashgate

Ivakhiv, A. J. (2001). Claiming sacred ground. Pilgrims and politics at Glastonbury and Sedona. Indianapolis: Indiana University Press.

Khalsa, P. S. ed. (1981). A pilgrim's guide to planet earth: A traveler's handbook and New Age directory. London: Wildwood House.

Lovelock, J. E. (1979). Gaia: A new look at life on Earth. Oxford/New York: Oxford University Press.

Luhrmann, T. M. (1989). Persuasions of the Witch's Craft: Ritual Magic in Contemporary England. Cambridge, (Massachusetts): Harvard University

MacCannell, D. (1976). The Tourist: A New Theory of the Leisure Class. New York: Schoken Books.

Magliocco, S. (2004). Witching Culture: Folklore and Neo-Paganism in America. Philadelphia: University of Pennsylvania Press

Morinis, A. (1992). ed. Sacred Journeys: The Anthropology of Pilgrimage. Westport, CT: Greenwood Press

Rountree, K. (2002). Goddess pilgrims as tourists: inscribing the body through sacred travel. Sociology of Religion 63, (4).

Rountree, K. (2006a). Performing the divine: Neo-Pagan pilgrimages and embodiment at sacred sites. Body and Society 12 (4), 95-115.

Rountree, K. (2006b). Journeys to the Goddess: Pilgrimage and tourism in the New Age. In On the Road to Being There: Pilgrimage and Religious Tourism in Late Modernity, ed. William Swatos, 33-60. Boston: Brill.

Pike, S. M. (2001) Earthly Bodies, Magical Selves. Contemporary Pagans and the Search for Community. Berkeley and Los Angeles: University of California Press. 
Reader, I. and Walter, T. eds. (1993). Pilgrimage in Popular Culture. London: Macmillan.

Salomonsen, J. (2002). Enchanted Feminism. The Reclaiming Witches of San Francisco. London: Routledge.

Smith, Valene L. 1992. "Introduction: The Quest in Guest." In "Pilgrimage and Tourism: The Quest in Guest," ed. Valene L. Smith. Special issue, Annals of Tourism Research 19:1-17.

Sumption, J. (1975). Pilgrimage: An Image of Medieval Religion. Lanham (Maryland): Rowman and Littlefield

Taylor, J. P. (2001). Authenticity and Sincerity in Tourism. Annals of Tourism Research 28:7-26.

Turnbull, C. (1992). Postscript: Anthropology as Pilgrimage, Anthropologist as Pilgrim. In: Morinis, Alan ed. Sacred Journeys: The Anthropology of Pilgrimage. Westport, CT: Greenwood Press.

Watkins, A. (1984 orig.1925). The old straight track. London: Sphere Books.

Weibel, D. (2001). Kidnapping the Virgin: The reinterpretation of a Roman Catholic shrine by Religious Creatives. Unpublished $\mathrm{PhD}$ thesis, University of California, San Diego.

Weibel, D. (2005). Of consciousness changes and fortified faith: Creativist and Catholic pilgrimage at French Catholic Shrines. In: Jill Dubisch and Michael Winkelman eds. Pilgrimage and healing, 111-134. Tucson: The University of Arizona Press.

Zwissler, L. (2011). Pagan Pilgrimage: New Religious Movements Research on Sacred Travel within Pagan and New Age Communities. Religion Compass, 5: 326-342. 